\title{
A new macropterous genus with a new species of Vianaididae (Heteroptera, Tingoidea, Vianaididae) from Peru
}

\author{
SARA I. MONTEMAYOR \& DIEGO L. CARPINTERO \\ División Entomología, Museo de Ciencias Naturales de La Plata, UNLP, Buenos Aires, Argentina
}

\begin{abstract}
In the present contribution a new genus and species is described and illustrated, Pterovianaida melchiori, from Peru. This is the first non-fossil macropterous Vianaididae known and it is the first time this family is reported from Peru.
\end{abstract}

Keywords: Macropterous, new genus, new species, Peru, Vianaididae

\section{Introduction}

The Vianaididae are a small group of very peculiar Heteroptera. Recent genera are exclusively distributed in the Neotropical Region and correspond to coleopteroid forms. Fossil genera are submacropterous or macropterous and belong to the Cretaceous amber of New Jersey. Up to now four Vianaididae genera were known: Anommatocoris China, 1945 with three species from Argentina, Panama and Trinidad; Thaumamannia Drake and Davis, 1960 with two species from Bolivia, Surinam and Guyana; Vianagramma Golub and Popov, 2000 and Vianathauma Golub and Popov, 2003, both of them fossil and monotypic. Although all recent species correspond to coleopteroid forms with vestigial eyes and completely coriaceous hemelytra, and are characterized by their myrmecophilous (Schuh \& Štys, 1991; Schuh \& Slater, 1995), some macropterous individuals that remain as are mentioned in the bibliography.

While Vianaididae were originally described by Kormilev (1955) as a family close to Tingidae, Drake \& Davis (1960) considered them as a group of highly specialized Tingids and therefore changed their status to subfamily. Some authors followed these criteria (Drake \& Froeschner 1962; Drake \& Ruhoff 1965; Doesburg 1977; Schuh \& Štys 1991; Schuh \& Slater 1995) but other disagreed and treated the vianaidids as a family (Scudder 1959; Carayon 1962; Štys \& Kerzhner 1975; Froeschner 1996; Lis 1999; Golub \& Popov 1998, 2000, 2003; Guilbert, 2001). The fossil macropterous genus Vianagramma provided new key evidence to establish Vianaididae as a family and to consider the Tingidae as a close but distinct lineage.

In this contribution we describe a new macropterous genus composed of one species from Peru, which is also the first Vianadidae identified for this country.

\section{Results}

Pterovianaida gen. n.

Head (Figure 1). Triangular in dorsal view, convex above. Eyes well developed, in dorsal view drop-like, in lateral view ovate, higher than wide; ocelli absent. Bucculae very narrow, subrectangular in lateral view, in ventral view subparallel, contiguous. Antennae (Figure 2) moderately long and slender, segments II, III and IV subequal, approximately three times segment I. Segment I barrel-shaped, segment II slightly claviform, segments III and IV cylindrical, wider at the center.

Correspondence: D. L. Carpintero, Museo de Ciencias Naturales de La Plata, División Entomología, Paseo del Bosque s/n 1900 La Plata, Buenos Aires, Argentina. Fax: 0054221 4257527. Email: dcarpint@fcnym.unlp.edu.ar 

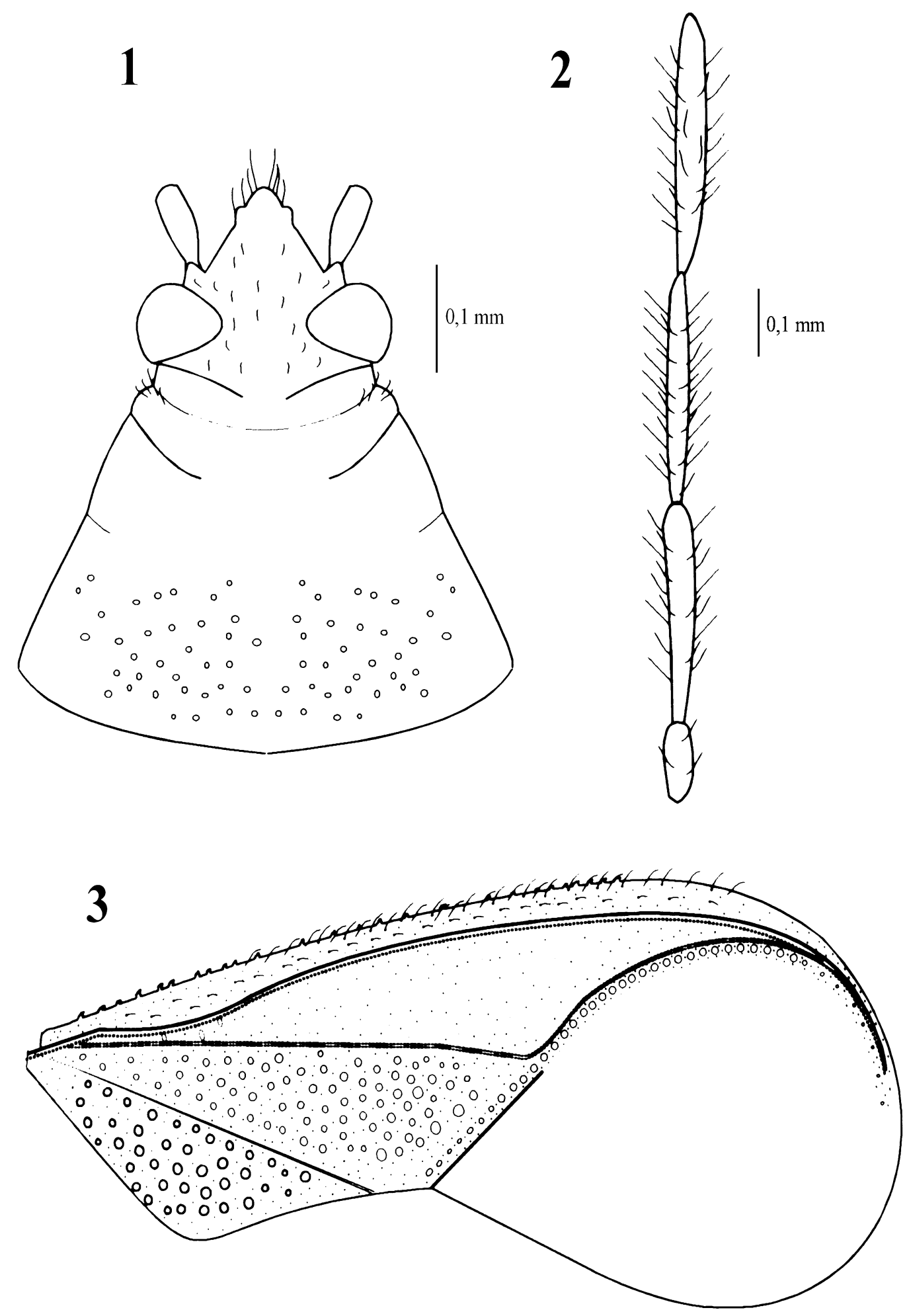

Figures 1-3. (1) Head and thorax, dorsal view. (2) Antennae. (3) Fore wing.

Thorax. Pronotum (Figure 1) with anterior lobe smooth, weakly elevated; posterior lobe with small scattered punctuations; collar slightly raised. Paranota carina-like. Scutellum well developed with small scattered punctuations. Metathoracic scent gland (Figure 4) provided with a Y-shaped peritreme that covers the entire metapleuron. Fore wings (Figure 3 ) with defined membrane and clavus, punctuated, with long, erect, scattered hairs except for membrane; outer margins serrated. Clavus welldeveloped and punctuated, costal area narrow with one row of small rounded punctuations; subcostal 
area narrow at base of hemelytra, widest at base of membrane, from there gradually narrowing down following the margins of the costal area but not surrounding it completely; discoidal area triangular, widest part with six rows of punctuations; membrane without nervures.

Legs. Slender, procoxae more separated from mesocoxae than the latter from metacoxae.

Abdomen. Ventrally covered with scattered long, white, semidecumbent hairs.

Type-species by present designation. Pterovianaida melchiori sp. $\mathrm{n}$.

Etymology. Ptero- in allusion to their macropterous condition; vianaida- to indicate yet another genus in the family.

\section{Pterovianaida melchiori sp. $\mathrm{n}$.}

Body brownish, antennae and legs reddish brown, clothed with long, slender, scattered, suberect hairs. Total length $2.45 \mathrm{~mm}$.

Head (Figure 1). Slightly granulated, covered with macrochaetae, scattered and slightly curved. Length $0.23 \mathrm{~mm}$, width across eyes $0.3 \mathrm{~mm}$. Interocular space $0.09 \mathrm{~mm}$. Rostrum reaching second abdominal segment. Antennae (Figure 2) covered with suberect hairs that have the same length as width of antennal segment interspersed with hairs twice the length of width of antennae. Length segment $\mathrm{I}=0.11 \mathrm{~mm} ; \quad \mathrm{II}=0.31 \mathrm{~mm}$; $\mathrm{III}=0.33 \mathrm{~mm}$; IV $=0.37 \mathrm{~mm}$.

Thorax. Pronotum length $0.32 \mathrm{~mm}$; basal width $0.6 \mathrm{~mm}$. Collar presents in anterior and lateral margins a few long erect hairs. Metathoracic scent gland (Figure 4) with anterior branch curved downwards, more developed and raised than posterior branch; the latter slender and directed backwards. Rostral channel faintly developed.

Abdomen. Pygophore (Figure 5) narrower than the rest of the abdomen; lateral margins glabrous, posterior margin covered with long, thin, erect hairs interspersed with shorter ones; dorsally at its posterior margin it invaginates and then protrudes as a flat projection; ventrally it forms a uniform lobe. Paramere glabrous, curved, gradually narrows towards the apex which is romus; posterior margin with two lobes at its base, the first more obvious than the second.

Material examined. Holotype male, Peru, Ucayali, Kirigueti (light trap), $73^{\circ} 07^{\prime} 08^{\prime \prime} \mathrm{W}, 11^{\circ} 38^{\prime} 13^{\prime \prime} \mathrm{S}$,
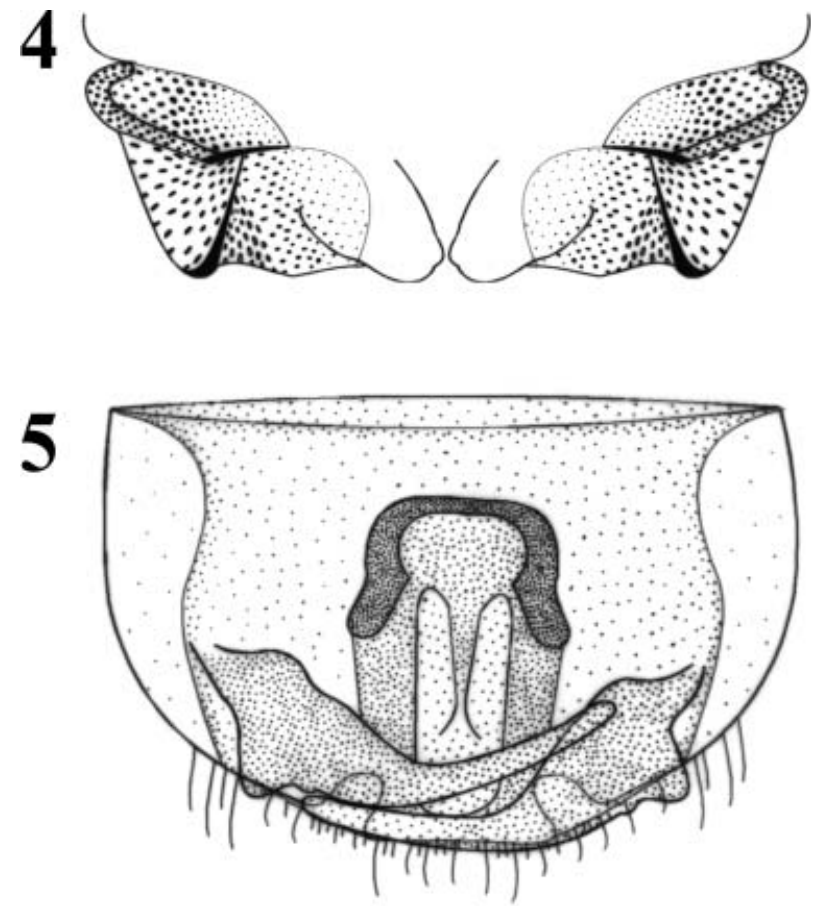

Figures 4, 5. (4) Metathoracic scent gland. (5) Pygophore.

August 2004, J. Williams coll., (slide mounted), in the collection of the Museo de La Plata (MLP).

Etymology. This species is dedicated to Melchior Borsinger, grandfather of the first author.

\section{Discussion}

The following features of Vianaididae are considered as plesiomorphic state: presence of macrochetae on head; absence of posterior projection of pronotum, and as a result, the exposed scutellum and completely uncovered clavus; transparent membrane; presence of real bladderlike pulvilli; symmetrical parameres and absence of protrusions in head and pronotum (Golub \& Popov, 1998). All these features are present in Pterovianaida except for the bladderlike pulvilli, so it should be considered a basal taxon of Vianaididae.

The macropterous form described here shares with the submacropterous genus Vianagramma the following characteristics: hemelytra divided into corium, clavus and membrane; corium areolate and divided by longitudinal veins into costal, subcostal, discoidal and sutural areas; compound eyes well developed; ocelli absent; presence of macrochetae on the head and membrane with one row of very small, punctuated cells in its outer margin. The main differences between these two genera are a longer rostrum, absence of pronotal carina and transverse hemelytral veins in Pterovianaida. 
Vianathauma shares with Pterovianaida the compound eyes well developed; and absence of pronotal carinae. However, it differs in having a shorter rostrum; hemelytra only divided into corium and membrane, clavus not differentiated; hemelytra surface not areolated; corium divided only in costal area; paranota absent; ocelli present and macrochetae absent.

\section{Acknowledgments}

We want to express our gratitude to J. Williams, herpetologist researcher of the Museo de La Plata de Ciencias Naturales (MNLP) for collecting the material and to Pluspetrol Perú Corporation S.A. for the financial support of the field work.

\section{References}

Carayon J. 1962. Observations sur l'appareil odorifique de hétéropteres particulierement celui de Tingidae, Vinanaididae et Piesmatidae. Cah Nat n.s. 18:1-16.

China WE. 1945. A completely blind bug of the family Lygaidae (Hemiptera, Heteroptera). Proc R Entomol Soc Lond 14:126-128.

Doesburg PH Van. 1977. A new species of Thaumamannia from Surinam (Heteroptera, Tingidae, Vianaidinae). Zool Meded 52:185-189.

Drake CJ, Davis NT. 1960. The morphology, phylogeny and higher classification of the family Tingidae, including description of a new genus and species of the subfamily Vianaidinae (Hemiptera: Heteroptera). Entomol Am 39:1-100.

Drake CJ, Froeschner RC. 1962. A new myrmecophilous lacebug from Panama (Hemiptera: Tingidae). Great Basin Nat 22:8-11.

Drake CJ, Ruhoff FA. 1965. Lacebugs of the world, a catalog (Hemiptera: Tingidae). U S Natl Mus Bull 243:1-634.
Froeschner RC. 1996. Lace bug genera of the world. I: Introduction, subfamily Cantacaderinae (Heteroptera: Tingidae). Washington: Smithsonian Institution Press. $43 \mathrm{p}$.

Golub VB, Popov Y. 1999. Composition and evolution of Cretaceous and Cenozoic faunas of bugs of the superfamily Tingoidea (Heteroptera: Cimicomorpha). AMBA project AM/PFICM 98/1. 99. In Proceedings of the First International Palaeoentomological Conference, Bratislava. p. 33-39.

Golub VB, Popov Y. 2000. A remarkable lace bug from Upper Cretaceous New Jersey amber (Heteroptera: Tingoidea, Vianaididae), with some phylogenetic commentary. In: Grimaldy D, editor. Studies on fossils in amber, with particular references to the Cretaceous of New Jersey. Leiden: Backuys. p.231-239.

Golub VB, Popov Y. 2003. The new fossil genus Vianaididae (Heteroptera: Tingoidea) from the Cretaceous amber of New Jersey; evolution of the family in the Late Cretaceous. Acta Zool Cracov 46:109-116.

Guilbert E. 2001. Phylogeny and evolution of exaggerated traits among the Tingidae (Heteroptera, Cimicomorpha). Zool Scr 30:313-324.

Kormilev NA. 1955. A new mirmecophil family of Hemiptera from the delta of Rio Parana, Argentina. Rev Ecuatoriana Entomol Paras 2:465-477.

Lis B. 1999. Phylogeny and classification of Cantacaderini [= Cantacaderidae Stat. Nov.] (Hemiptera: Tingoidea). Ann Zool (Wars) 49:157-196.

Schuh RT, Slater JA. 1995. Tingidae. In: Schuh RT, Slater JA, editors. True bugs of the world (Hemiptera: Heteroptera). Ithaca (NY): Cornell University Press. p.180-184.

Schuh RT, Štys P. 1991. Phylogenetic analysis of cimicomorphan family relationships (Heteroptera). J N Y Entomol Soc 99:298-350.

Scudder GGE. 1959. The female genitalia of the Heteroptera: morphology and bearing on classification. Proc R Entomol Soc Lond 111:405-467.

Štys P, Kerzhner IM. 1975. The rank and nomenclature of higher taxa in recent Heteroptera. Acta Entomol Bohemoslov 72:65-79. 